\title{
PERANAN SEKTOR PERTANIAN TERHADAP PEREKONOMIAN KABUPATEN BOLAANG MONGONDOW SELATAN
}

\author{
Olvie Nanda Sasue \\ Grace A. J. Rumagit \\ Mex L. Sondakh
}

\begin{abstract}
This study aims to determine the role of the agricultural sector to the economy of South Bolaang Mongondow Regency and its development in the period of 5 years ie in 2010 until 2014 and also to know the agricultural sector is the base or non-base sector. The data used is secondary data. This secondary data is obtained from the relevant agencies namely the Central Bureau of Statistics of North Sulawesi Province. The data is then analyzed using contribution formulas, growth formula and Location Quotient (LQ) analysis. The results showed that the agricultural sector is the largest contributor to the economy of Bolaang Mongondow Selatan Regency. This can be seen from the calculation of contribution and development of agricultural sector contribution to South Bolaang Mongondow Regency PDRB from 2010 to 2014. Based on the results of research also known that the development of agriculture sector to PDRB shows an increase that is from 2010-2014 with the largest increase occurred in 2013 with growth reached 5.82\%, this can be interpreted that the productivity of agricultural sector in South Bolaang Mongondow Regency is good. From the analysis result using LQ, it can be seen that agriculture sector is base sector in South Bolaang Mongondow Regency, it means the role of agricultural sector in Bolaang Mongondow Selatan Regency is bigger.
\end{abstract}

Keywords: role, agriculture sector, economy, South Bolaang Mongondow District

\begin{abstract}
ABSTRAK
Penelitian ini bertujuan untuk mengetahui peranan sektor pertanian terhadap perekonomian Kabupaten Bolaang Mongondow Selatan dan perkembangannya dalam kurun waktu 5 tahun yaitu tahun 2010 sampai tahun 2014 dan juga untuk mengetahui sektor pertanian merupakan sektor basis atau non basis. Data yang digunakan adalah data sekunder. Data sekunder ini diperoleh dari Badan Pusat Statistik Provinsi Sulawesi Utara. Data tersebut kemudian di analisis menggunakan rumus kontribusi, rumus pertumbuhan dan analisis Location Quotient (LQ). Hasil penelitian menunjukkan bahwa sektor pertanian merupakan kontributor terbesar terhadap perekonomian wilayah Kabupaten Bolaang Mongondow Selatan. Hal ini dapat dilihat dari perhitungan kontribusi dan perkembangan kontribusi sektor pertanian terhadap PDRB Kabupaten Bolaang Mongondow Selatan dari tahun 2010 sampai tahun 2014. Berdasarkan hasil penelitian juga diketahui bahwa perkembangan sektor pertanian terhadap PDRB menunjukkan peningkatan yaitu dari tahun 2010-2014 dengan peningkatan terbesar terjadi pada tahun 2013 dengan pertumbuhan mencapai 5,82\%, hal ini dapat diartikan bahwa produktivitas sektor pertanian di Kabupaten Bolaang Mongondow Selatan sudah baik. Dari hasil analisis menggunakan LQ, dapat diketahui bahwa sektor pertanian merupakan sektor basis di Kabupaten Bolaang Mongondow Selatan, artinya peran sektor pertanian di Kabupaten Bolaang Mongondow Selatan lebih besar.
\end{abstract}

Kata kunci: peranan, sektor pertanian, perekonomian, Kabupaten Bolaang Mongondow Selatan 


\section{PENDAHULUAN}

\section{Latar Belakang}

Pembangunan ekonomi merupakan upaya yang dilakukan pemerintah dalam memberikan kesejahteraan ekonomi yang lebih baik bagi masyarakatnya. Dalam suatu daerah, pembangunan ekonomi adalah suatu proses kerja sama antara pemerintah daerah dan masyarakatnya dalam mengelola sumberdayasumberdaya yang ada dan membentuk suatu pola kemitraan antara pemerintah daerah dengan sektor swasta untuk menciptakan suatu lapangan kerja baru dan merangsang perkembangan kegiatan ekonomi di wilayah tersebut (Laoh, 2010). Manfaat makro bertalian dengan bagaimana pemerintah dapat melakukan usaha pembangunan regional untuk mempercepat laju pertumbuhan keseluruhan wilayah, yaitu kenaikan seluruh nilai tambah di wilayah tersebut. Oleh karena itu, pemerintah harus mampu melihat keunggulan dan kelemahan dari setiap sektor diwilayahnya. Sektor yang memiliki keunggulan, prospeknya lebih baik untuk dikembangkan dan di harapkan dapat menjadi pendorong sektor-sektor lain untuk berkembang (Tarigan, 2005). Pembangunan ekonomi daerah merupakan suatu proses dimana pemerintah daerah dan masyarakat mengelola sumbedaya-sumberdaya yang ada, dengan menjalin pola-pola kemitraan antara pemerintah daerah dan pihak swasta guna penciptaan lapangan kerja, serta dapat merangsang pertumbuhan ekonomi di daerah bersangkutan (Soeparmoko, 2002). Aktifitas dalam perekonomian regional digolongkan dalam dua sektor yakni: aktifitas basis dan non basis, kegiatan basis merupakan kegiatan yang melakukan aktifitas yang berorientasi ekspor (barang dan jasa) keluar batas wilayah perekonomian yang bersangkutan. Aktifitas basis memiliki peranan penggerak utama (primer mover) dalam pertumbuhan suatu wilayah. Setiap perubahan yang terjadi pada sektor basis menimbulkan efek ganda (multiplier effect) dalam perekonomian regional. Kegiatan non basis adalah kegiatan yang menyediakan barang dan jasa yang dibutuhkan masyarakat yang berada di dalam batas wilayah perekonomian yang bersangkutan. Luas lingkup produksi dan pemasaran adalah bersifat lokal inti dari model ekonomi basis (economic base model) bahwa arah dan pertumbuhan suatu wilayah ditentukan oleh ekspor wilayah tersebut. Untuk mengukur sejauh mana perkembangan atau pembangunan suatu daerah maka digunakan indikator. Indikator tersebut terdiri dari indikator ekonomi dan indikator nonekonomi atau sosial (Kuncoro, 1997). Salah satu indikator ekonomi yang digunakan untuk mengukur sejauh mana perkembangan ekonomi suatu daerah adalah dengan melihat PDRB daerah tersebut, sebab PDRB dapat menunjukkan tingkat aktivitas perekonomian suatu daerah. Makin tinggi PDRB suatu daerah maka ini bias berarti tingkat kegiatan perekonomian di daerah tersebut juga tinggi demikian juga sebaliknya. PDRB di Indonesia pada dasarnya terdiri dari 9 sektor, salah satunya sector pertanian. Pertanian merupakan salah satu sektor penggerak ekonomi Provinsi Sulawesi Utara karena wilayahnya sebagian besar merupakan lahan pertanian. Selain itu, penduduk di Provinsi Sulawesi Utara sebagian besar bermata pencaharian sebagai petani. Kabupaten Bolaang Mongondow Selatan adalah kabupaten yang baru dimekarkan pada tahun 2008, kabupaten ini dibentuk berdasarkan UndangUndang Nomor 30 Tahun 2008. Walaupun Kabupaten Bolaang Mongondow Selatan tergolong baru kabupaten ini memiliki banyak potensi ekonomi. Berikut ini Tabel 1, PDRB Kabupaten Bolaang Mongondow Selatan tahun 2010-2014.

Tabel 1. PDRB Tahun 2010-2014 Atas Dasar Harga Konstan Tahun 2010 Kabupaten Bolaang Mongondow Selatan (Juta Rupiah)

\begin{tabular}{|c|c|c|c|c|c|}
\hline $\begin{array}{c}\text { LAPANGAN } \\
\text { USAHA }\end{array}$ & 2010 & 2011 & 2012 & 2013 & 2014 \\
\hline $\begin{array}{l}\text { 1. Pertanian, } \\
\text { Kehutanan \& }\end{array}$ & & & & & \\
\hline $\begin{array}{l}\text { Perikanan } \\
\text { 2.Pertambangan \& }\end{array}$ & $330,209.8$ & $337,751.7$ & $355,585.2$ & $376,281.7$ & $390,957.2$ \\
\hline $\begin{array}{l}\text { Penggalian } \\
\text { 3. Industri }\end{array}$ & $44,300.0$ & $47,994.0$ & $52,157.1$ & $56,777.1$ & $63,105.7$ \\
\hline $\begin{array}{l}\text { Pengolahan } \\
\text { 4. Pengadaan Listrik }\end{array}$ & $5,477.5$ & $5,966.3$ & $6,257.1$ & $6,720.7$ & $7,078.8$ \\
\hline $\begin{array}{l}\text { \& Gas } \\
\text { 5. Pengadaan Air, }\end{array}$ & 261.1 & 280.2 & 312.1 & 353.3 & 388.8 \\
\hline $\begin{array}{l}\text { Pengelolaan } \\
\text { Sampah, Limbah \& } \\
\text { Daur Ulang }\end{array}$ & $3,165.3$ & $3,318.8$ & $3,563.2$ & $3,823.3$ & $3,963.2$ \\
\hline $\begin{array}{l}\text { 6. Konstruksi } \\
\text { 7. Perdagangan }\end{array}$ & $76,466.5$ & $84,480.2$ & $93,826.3$ & $104,373.4$ & $120,779.6$ \\
\hline $\begin{array}{l}\text { Besar \& Eceran: } \\
\text { Reparasi Mobil \& } \\
\text { Sepeda Motor } \\
\text { 8. Transportasi \& }\end{array}$ & $66,473.8$ & $71,306.5$ & $76,635.9$ & $82,410.0$ & $89,548.2$ \\
\hline $\begin{array}{l}\text { Pergudangan } \\
\text { 9. Penyediaan } \\
\text { Akomodasi \& }\end{array}$ & $21,141.0$ & $22,416.1$ & $23,835.9$ & $25,263.1$ & $26,893.6$ \\
\hline $\begin{array}{l}\text { Makan } \\
\text { Minum }\end{array}$ & $3,452.6$ & $3,545.2$ & $3,626.8$ & $3,791.5$ & $3,959.4$ \\
\hline $\begin{array}{l}\text { 10. Informasi \& } \\
\text { Komunikasi } \\
\text { 11. Jasa Keuangan \& }\end{array}$ & $1,048.1$ & $1,081.3$ & $1,150.0$ & $1,223.6$ & $1,317.6$ \\
\hline Asuransi & $3,196.4$ & $3,358.1$ & $3,633.2$ & $3,918.3$ & $4,123.4$ \\
\hline 12. Real Estate & $22,239.0$ & $23,847.8$ & $25,309.9$ & $27,203.4$ & $29,312.9$ \\
\hline $\begin{array}{l}\text { 13. Jasa Perusahaan } \\
\text { 14.Administrasi }\end{array}$ & 103.2 & 109.9 & 115.4 & 125.6 & 133.9 \\
\hline $\begin{array}{l}\text { Pemerintahan, } \\
\text { Pertahanan \& } \\
\text { Jaminan Sosial } \\
\text { Wajib }\end{array}$ & $83,508.5$ & $90,351.3$ & $98,086.9$ & $105,888.1$ & $115,935.3$ \\
\hline $\begin{array}{l}\text { 15. Jasa Pendidikan } \\
\text { 16. Jasa Kesehatan }\end{array}$ & $63,845.0$ & $68,729.6$ & $73,278.2$ & $78,282.7$ & $84,337.2$ \\
\hline $\begin{array}{l}\text { \& Kegiatan } \\
\text { Sosial }\end{array}$ & $24,284.1$ & $26,405.9$ & $28,711.8$ & $30,726.6$ & $33,033.1$ \\
\hline 17. Jasa Lainnya & $4,735.3$ & $4,954.2$ & $5,241.5$ & $5,555.1$ & $6,039.4$ \\
\hline PDRB & $753,907.1$ & $795,897.1$ & $851,326.6$ & $912,717.5$ & $980,907.3$ \\
\hline
\end{tabular}


Dari Tabel 1 menunjukkan bahwa sektor pertanian merupakan penyumbang PDRB terbesar, sehingga dalam pembangunan ekonomi pertanian memiliki peranan yang signifikan. Hal ini yang melatar belakangi penelitian ini yang ingin mengetahui bagaimana peranan sektor pertanian dalam perekonomian Kabupaten Bolaang Mongondow Selatan.

\section{Perumusan Masalah}

Berdasarkan latar belakang yang telah diuraikan, maka yang menjadi rumusan masalah dalam penelitian ini adalah:

1. Berapa besar peranan sektor pertanian terhadap perekonomian Kabupaten Bolaang Mongondow Selatan dari tahun 2010-2014?

2. Bagaimana perkembangan peranan dalam bentuk nilai PDRB sektor pertanian terhadap pereonomian Kabupaten Bolaang Mongondow Selatan dari tahun 2010-2014?

3. Apakah sektor pertanian merupakan sektor basis di Kabupaten Bolaang Mongondow Selatan, dan sub sektor apakah di sektor pertanian Kabupaten Bolaang Mongondow Selatan yang merupakan sektor basis?

\section{Tujuan Penelitian}

Tujuan diadakanya penelitian ini adalah:

1. Mendeskripsikan peranan sektor pertanian terhadap perekonomian Kabupaten Bolaang Mongondow Selatan.

2. Melihat perkembangan peranan dalam bentuk nilai PDRB sektor pertanian terhadap perekonomian Kabupaten Bolaang Mongondow Selatan dari tahun 2010-2014.

3. Menganalisis sektor pertanian merupakan sektor basis atau non basis di Kabupaten Bolaang Mongondow Selatan dan sub sektor di sektor pertanian Kabupaten Bolaang Mongondow Selatan yang merupakan sektor basis.

\section{Manfaat Penelitian}

Penelitian diharapkan dapat bermanfaat baik sebagai bahan informasi di bidang perencanaan dan pembangunan wilayah, maupun sebagai masukan dan kajian bagi penelitian selanjutnya.

\section{METODOLOGI PENELITIAN}

\section{Metode Pengumpulan data}

Data yang digunakan dalam penelitian ini berupa data sekunder yang diperoleh dari
Badan Pusat Statistik dan Instansi terkait lainnya.

\section{Konsep Pengukuran Variabel}

Variabel-variabel yang diukur dalam

1. Nilai PDRB Provinsi Sulawesi Utara tahun 2010-2014 atas dasar harga konstan tahun 2010 (Rupiah).

2. Nilai PDRB Kabupaten Bolaang Mongondow Selatan tahun 2010-2014 atas dasar harga konstan tahun 2010 (Rupiah).

3. Kontribusi sektor pertanian terhadap PDRB 2010-2014 Kabupaten Bolaang Mongondow Selatan (\%).

4. Perkembangan kontribusi sektor pertanian dari tahun 2010-2014 (\%).

\section{Analisis Data}

Analisis data yang di gunakan dalam penelitian ini adalah analisis:

1. Untuk melihat kontribusi sektor pertanian terhadap perekonomian Kabupaten Bolaang Mongondow Selatan digunakan rumus:

$$
\text { Kontribusi }=\frac{\text { jumlahPDRBsektorpertanian }}{\text { jumlahPDRBseluruhsektor }} 100
$$

2. Untuk menghitung laju pertumbuhan/perkembangan PDRB sektor pertanian maka digunakan rumus:

$$
G t=\frac{P D R B_{t}-P D R B_{t-1}}{P D R B_{t-1}} \times 100
$$

3. Untuk mengetahui apakah sektor pertanian merupakan sektor basis atau non basis dalam perekonomian wilayah Kabupaten Bolaang Mongondow Selatan, maka digunakan analisis Location Quotient (LQ) dengan rumus sebagai berikut:

$$
L Q=\frac{l_{i} / e}{L_{i} / E}
$$

$1_{\mathrm{i}}=$ Jumlah PDRB sektor pertanian Kabupaten Bolaang Mongondow Selatan

e = Jumlah PDRB seluruh sektor Kabupaten Bolaang Mongondow Selatan

$\mathrm{L}_{\mathrm{i}}=$ Jumlah PDRB sektor pertanian Provinsi Sulawesi Utara

$\mathrm{E}=$ Jumlah PDRB seluruh sektor Provinsi Sulawesi Utara

1) Untuk mengetahui sub sektor tanaman bahan pangan merupakan subsektor basis atau non basis dalam perekonomian wilayah Kabupaten 
Bolaang Mongondow Selatan, maka rumus yang digunakan adalah:

$$
L Q=\frac{l_{a} / e}{L_{a} / E}
$$

La = Jumlah PDRB sub sektor tanaman bahan pangan Kabupaten Bolaang Mongondow Selatan

$\mathrm{e}=$ Jumlah PDRB sektor pertanian Kabupaten Bolaang Mongondow Selatan

$\mathrm{L}_{\mathrm{a}}=$ Jumlah PDRB sub sektor tanaman bahan pangan Provinsi Sulawesi Utara

$\mathrm{E}=$ Jumlah PDRB sektor pertanian Provinsi Sulawesi Utara

2) Untuk mengetahui sub sektor perkebunan merupakan sub sektor basis atau non basis dalam perekonomian wilayah Kabupaten Bolaang Mongondow Selatan, maka rumus yang digunakan adalah:

$$
L Q=\frac{l b / \mathrm{e}}{L b / E}
$$

$1_{\mathrm{b}}=$ Jumlah PDRB sub sektor perkebunan

Kabupaten Bolaang Mongondow Selatan

$\mathrm{e}=$ Jumlah PDRB sektor pertanian Kabupaten Bolaang Mongondow Selatan

$\mathrm{L}_{\mathrm{b}}=$ Jumlah PDRB sub sektor perkebunan Provinsi Sulawesi Utara

3) Untuk mengetahui sub sektor kehutanan merupakan sub sektor basis atau non basis dalam perekonomian wilayah Kabupaten Bolaang Mongondow Selatan, maka rumus yang digunakan adalah:

$$
L Q=\frac{l c / \mathrm{e}}{L c / E}
$$

$1_{c}=$ Jumlah PDRB sub sektor kehutanan Kabupaten Bolaang Mongondow Selatan

$\mathrm{e}=$ Jumlah PDRB sektor pertanian Kabupaten Bolaang Mongondow Selatan

$\mathrm{L}_{\mathrm{c}}=$ Jumlah PDRB sub sektor kehutanan Provinsi Sulawesi Utara

$\mathrm{E}=$ Jumlah PDRB sektor pertanian Provinsi Sulawesi Utara

4) Untuk mengetahui sub sektor peternakan merupakan sub sektor basis atau non basis dalam perekonomian wilayah Kabupaten Bolaang Mongondow Selatan, maka digunakan rumus:

$$
L Q=\frac{l d / \mathrm{e}}{L d / E}
$$

$1_{d}=$ Jumlah PDRB sub sektor peternakan Kabupaten Bolaang Mongondow Selatan

$\mathrm{e}=$ Jumlah PDRB sektor pertanian Kabupaten Bolaang Mongondow Selatan

$\mathrm{L}_{\mathrm{d}}=$ Jumlah PDRB sub sektor peternakan Provinsi Sulawesi Utara

$\mathrm{E}=$ Jumlah PDRB sektor pertanian Provinsi Sulawesi Utara (Sumber: Tarigan, 2005)

5) Untuk mengetahui sub sektor perikanan merupakan sub sektor basis atau non basis dalam perekonomian wilayah Kabupaten Bolaang Mongondow Selatan, maka digunakan rumus:

$$
L Q=\frac{l e / \mathrm{e}}{L e / E}
$$

$l_{\mathrm{d}}=$ Jumlah PDRB sub sektor perikanan Kabupaten Bolaang Mongondow Selatan

$\mathrm{e}=$ Jumlah PDRB sektor pertanian Kabupaten Bolaang Mongondow Selatan

$\mathrm{L}_{\mathrm{e}}=$ Jumlah PDRB sub sektor perikanan Provinsi Sulawesi Utara

$\mathrm{E}=$ Jumlah PDRB sektor pertanian Provinsi Sulawesi Utara

Jika nilai LQ > 1 , maka sektor tersebut merupakan sektor basis, jika nilai LQ $<1$ maka sektor tersebut merupakan sektor non basis. Apabila LQ > 1 artinya peranan sektor tersebut di Kabupaten Bolaang Mongondow Selatan lebih menonjol dari pada peranan sektor itu di tingkat Provinsi. Sebaliknya, apabila LQ $<1$ maka peranan sektor itu lebih kecil di Kabupaten Bolaang Mongondow Selatan daripada peranan sektor tersebut I tingkat Provinsi.

\section{HASIL DAN PEMBAHASAN}

\section{Keadaan Goegrafis Kabupaten Bolaang Mongondow Selatan}

Kabupaten Bolaang Mongondow Selatan merupakan daerah otonom baru hasil pemekeran dari Kabupaten Bolaang Mongondow yang dibentuk berdasarkan Undang-Undang Nomor 30 tahun 2008 tentang pembentukan Kabupaten Bolaang Mongondow Selatan di Provinsi Sulawesi Utara dengan Ibu Kota Molibagu. Kabupaten Bolaang Mongondow Selatan terdiri atas 6 kecamatan dengan 81 Desa. Luas wilayah Kabupaten Bolaang Mongondow Selatan, sesuai UU No 30 
tentang pembentukan Kabupaten Bolaang Mongondow Selatan adalah $\pm 193,23 \mathrm{Km}^{2}$ atau 1.932,30 Ha dengan rincian menurut luas per kecamatan seperti yang dapat dilihat Tabel 2.

Tabel 2. Luas Daerah Kabupaten Bolaang Mongondow

\begin{tabular}{lcc}
\multicolumn{3}{c}{ Selatan Menurut Kecamatan } \\
\hline \multicolumn{1}{c}{ Kecamatan } & Luas Area $\left(\mathrm{Km}^{2}\right)$ & Persentase $(\%)$ \\
\hline 1. Bolaang Uki & 393,43 & 31,93 \\
2. Posigadan & 729,00 & 27,74 \\
3. Pinolosian & 285,93 & 13,66 \\
4. Pinolosian & & \\
Timur & 221,87 & 10,10 \\
5. Pinolosian & & \\
Tengah & 302,07 & 7,88 \\
\hline Total & 193,23 & 100 \\
\hline
\end{tabular}

Sumber: Bolaang Mongondow Selatan dalam Angka 2016

Dari Tabel 2 dapat dilihat bahwa Kecamatan Bolaang Uki memliki luas area yaitu $393,43 \mathrm{Km}^{2}$ atau $31,93 \%$, Kecamatan Posigadan memiliki luas area $729,00 \mathrm{Km}^{2}$ atau $27,74 \%$, Kecamatan Pinolosian Timur memiliki luas area $221,87 \mathrm{Km}^{2}$ atau $10,10 \%$, Kecamatan Pinolosian memiliki luas area $285,93 \mathrm{Km}^{2}$ atau $13,66 \%$, dan Kecamatan Pinolosian Tengah memiliki luas area yaitu $302.07 \mathrm{Km}^{2}$ atau $7,88 \%$. Secara astronomis, wilayah Kabupaten Bolaang Mongondow Selatan terletak antara: 0025 "542" Lintang Utara dan 123028 " 54,2 " Bujur Timur. Dengan batasan administrasi sebagai berikut:

1. Sebelah Utara berbatasan dengan Kabupaten Bolaang Mongondow Utara

2. Sebelah Timur berbatasan dengan Kabupaten Bolaang Mongondow Timur

3. Sebelah Barat berbatasan dengan Provinsi Gorontalo

4. Sebelah Selatan berbatasan dengan Teluk Tomini

\section{Kondisi Kependudukan}

\section{Jumlah dan Komposisi Penduduk}

Dari tahun ke tahun jumlah penduduk di Kabupaten Bolaang Mongondow Selatan selalu mengalami peningkatan. Pada tahun 2015, penduduk di Kabupaten Bolaang Mongondow Selatan berjumlah 62.222 jiwa. Peningkatan jumlah penduduk ini disebabkan oleh besarnya angka kelahiran dibandingkan dengan angka kematiannya. Untuk lebih jelasnya data mengenai jumlah penduduk di Kabupaten Bolaang Mongondow Selatan tiap kecamatan dapat dilihat pada Tabel 3.
Tabel 3. Luas Wilayah dan Jumlah Penduduk Tiap Kecamatan di Kabupaten Bolaang Mongondow Selatan dan Kepadatan Penduduk

\begin{tabular}{lccc}
\hline \multicolumn{1}{c}{ Kecamatan } & Luas $(\mathrm{Km})$ & Penduduk & $\begin{array}{c}\text { Kepadatan } \\
\text { (orang/Km) }\end{array}$ \\
\hline 1. Bolaang Uki & 393,43 & 19.867 & 50,49 \\
2. Posigadan & 729,00 & 17.261 & 23,68 \\
3. Pinolosian & 285,93 & 8.498 & 29,72 \\
4. Pinolosian & & & \\
Timur & 221,87 & 6.285 & 28,33 \\
$\begin{array}{l}\text { 5. Pinolosian } \\
\text { Tengah }\end{array}$ & 302,07 & 4.904 & 16,23 \\
6. Helumo & & 5.407 & \\
\hline \multicolumn{1}{c}{ Jumlah } & 193,23 & 62.222 & 32,20 \\
\hline Sumber: Bolaang Mongondow Selatan dalam Angka 2016
\end{tabular}

Dari Tabel 3 dapat dilihat bahwa Kecamatan Bolaang Uki memiliki luas wilayah terbesar dengan 393,43 $\mathrm{Km}^{2}$ dengan jumlah penduduk 19.867 dengan kepadatan 50,49 orang $/ \mathrm{Km}^{2}$, Kecamatan Posigadan memiliki luas wilayah $729,00 \mathrm{Km}^{2}$ dengan jumlah penduduk 17.261 dengan kepadatan 23,68 orang $/ \mathrm{Km}^{2}$, Kecamatan Pinolosian memiliki luas wilayah 285,93 $\mathrm{Km}^{2}$ dengan jumlah penduduk 8.498 dengan kepadatan 29,72 orang/ $/ \mathrm{Km}^{2}$, Kecamatan Pinolosia Timur memiliki luas wilayah 221,87 $\mathrm{Km}^{2}$ dengan jumlah penduduk 6.285 dengan kepadatan 28,33 orang $/ \mathrm{Km}^{2}$, Kecamatan Pinolosian Tengah memiliki luas wilayah 302,07 $\mathrm{Km}^{2}$ dengan jumlah penduduk 4.904 dengan kepadatan 16,23 orang $/ \mathrm{Km}^{2}$. Dari Tabel 3 dapat disimpulkan bahwa penduduk di Kabupaten Bolaang Mongondow Selatan terkonsentrasi di dua kecamatan yaitu Kecamatan Posigadan dan Kecamatan Bolaang Uki. Berikut ini adalah Tabel 4 mengenai jumlah penduduk tiap kecamatan berdasarkan jenis kelamin dan rasio jenis kelamin di Kabupaten Bolaang Mongondow Selatan.

Tabel 4. Jumlah Penduduk Tiap Kecamatan Berdasarkan Jenis Kelamin dan Rasio Jenis Kelamin di Kabupaten Bolaang Mongondow Selatan

\begin{tabular}{lcccc}
\hline \multicolumn{1}{c}{ Kecamatan } & $\begin{array}{c}\text { Laki- } \\
\text { Laki }\end{array}$ & Perempuan & Jumlah & Rasio \\
\hline 1. Bolaang Uki & 10.274 & 9.593 & 19.867 & 107,10 \\
$\begin{array}{l}\text { 2. Posigadan } \\
\text { 3. Pinolosian }\end{array}$ & 8.931 & 8.33 & 17.261 & 107,21 \\
$\begin{array}{l}\text { 4. Pinolosian } \\
\text { Timur }\end{array}$ & 3.454 & 4.044 & 8.498 & 110,14 \\
$\begin{array}{l}\text { 5. Pinolosian } \\
\text { Tengah }\end{array}$ & 2.32 & 2.965 & 6.285 & 111,97 \\
6. Helumo & 2.815 & 2.592 & 5.407 & 108,60 \\
\hline \multicolumn{1}{c}{ Jumlah } & 32.399 & 29.823 & 62.222 & 108,64 \\
\hline
\end{tabular}

Sumber: Bolaang Mongondow Selatan dalam Angka 2016

Pada Tabel 4 kita dapat melihat perbandingan antara penduduk laki-laki dan perempuan di tiap-tiap kecamatan di Kabupaten Bolaang Mongondow Selatan pada tahun 2015. 
Kecamatan Bolaang Uki memiliki jumlah penduduk terbanyak di antara kecamatankecamatan lain di Kabupaten Bolaang Mongondow Selatan dengan 19.867 jiwa, selain itu di kecamatan ini memiliki jumlah penduduk laki-laki maupun perempuan paling banyak dengan kecamatan-kecamatan lain Kabupaten Bolaang Mongondow Selatan dengan rasio penduduk $107,10 \%$ atau dapat dikatakan bahwa setiap 100 jiwa penduduk dengan kelamin perempuan terdapat 107,10 jiwa laki-laki, sedangkan Kabupaten Bolaang Mongondow Selatan terdapat 62.222 jiwa dengan jumlah penduduk perempuan 29.823 dengan rasio 108,64 atau dapat diartikan setiap 100 penduduk perempuan di Kabupaten Bolaang Mongondow Selatan terdapat 107,10 laki-laki, sex ratio menunjukkan banyaknya jumlah penduduk laki-laki dalam 100 penduduk perempuan. Berikutnya Tabel 5 menunjukkan jumlah dan komposisi penduduk pada tahun 2015 di Kabupaten Bolaang Mongondow Selatan.

Tabel 5. Jumlah dan Komposisi Penduduk Kabupaten Bolaang Mongondow Selatan Tahun 2015 Menurut Kelompok Umur dan Jenis Kelamin

\begin{tabular}{|c|c|c|c|c|}
\hline $\begin{array}{l}\text { Kelompok } \\
\text { Umur }\end{array}$ & Laki-Laki & Perempuan & Jumlah & $\begin{array}{c}\text { Angka } \\
\text { Ketergantungan } \\
(\%)\end{array}$ \\
\hline $0-14$ & 11.582 & 10.922 & 22.504 & 40,1 \\
\hline $15-64$ & 20.817 & 18.901 & 39.718 & \\
\hline Total & 32.399 & 29.823 & 62.222 & 40,1 \\
\hline
\end{tabular}

Berdasarkan usia, penduduk digolongkan menjadi dua yaitu penduduk usia produktif dan usia non produktif. Penduduk usia produktif adalah penduduk yang berusia 15-64 tahun, sedangkan penduduk usia non produktif adalah yang berusia 0-14 tahun dan usia 65 tahun ke atas. Dari Tabel 5 dapat diketahui bahwa persentase angka ketergantungan pada tahun 2015 sebesar 40,1\%. Artinya setiap seratus penduduk anggota produktif harus menanggung 40 penduduk usia non produktif. Angka ketergantungan menunjukkan banyaknya penduduk non produktif yang menjadi tanggungan 100 orang penduduk usia produktif.

\section{Kondisi Bidang Pendidikan}

Pendidikan merupakan salah satu sarana dalam meningkatkan sumber daya manusia. Salah satu upaya pemerintah dalam rangka mengembangkan dan meningkatkan sumber daya manusia di bidang pendidikan yaitu dengan mencanangkan berbagai program seperti program wajib belajar 12 tahun dan lain-lain. Peningkatan partisipasi sekolah penduduk, tentunya harus diimbangi dengan penyediaan sarana pendidikan maupun tenaga guru yang memadai. Efektifitas proses belajar mengajar di kelas berhubungan dengan besar kecilnya beban tanggung jawab seorang guru membimbing murid atau rasio guru terhadap murid. Data tahun 2015 menunjukkan bahwa pada jenjang pendidikan $\mathrm{SD} /$ sederajat, rata-rata seorang guru bertanggung jawab terhadap membimbing 21 murid pada SD dan 8 murid pada Madrasah Ibtidaiyah (MI). Pada jenjang pendidikan SLTP rata-rata seorang guru mengajar 16 murid dan di jenjang SMA beban seorang guru hanya mengajar sebanyak 15 murid. Rasio ideal yang dikeluarkan Diknas adalah 22 murid per guru, artinya yang masih banyak dibutuhkan di Kabupaten Bolaang Mongondow Selatan adalah guru SMA/MA/SMK.

\section{Kondisi Ketenagakerjaan}

Jumlah angkatan kerja di tahun 2015 menjadi 58,54 persen dari total penduduk usia 15 tahun ke atas. Penurunan jumlah angkatan kerja tersebut juga diikuti oleh penurunan pengangguran di Kabupaten Bolaang Mongondow Selatan menjadi sebesar 6,78 persen. Hal ini dimungkinkan juga karena tenaga kerja yang tersedia tidak sesuai dengan kualifikasi dari lapangan kerja yang tersedia. Berdasarkan perbandingan menurut tiga sektor utama yaitu primer, sekunder, dan tersier pada tahun 2015, pilihan bekerja di sektor primer mendominasi pasar kerja di Kabupaten Bolaang Mongondow Selatan yaitu sebesar 60,64 persen, meskipun persentasenya mulai sedikit bergeser ke sektor sekunder jika dibandingkan dengan kondisi di tahun 2013. Sementara yang bekerja di sektor tersier meningkat sebesar 39,10 persen dan sekunder sebesar 5,49\%. Banyaknya angkatan kerja di Kabupaten Bolaang Mongondow Selatan pada tahun 2014 sebagian besar laki-laki. Dengan persentase 70 persen laki-laki dan 30 persen perempuan. 


\section{Kondisi Bidang Kesehatan}

Pembangunan kesehatan merupakan bagian integral dari pembangunan nasional dan bertujuan agar semua lapisan masyarakat memperoleh pelayanan kesehatan secara musah, leluasa dan murah. Dengan upaya tersebut diharapkan akan tercapai derajat kesehatan masyarakat yang baik. Upaya untuk meningkatkan derajat kesehatan masyarakat sudah banyak dilakukan oleh pemerintah antara lain dengan memberikan penyuluhan kesehatan, agar keluarga berperilaku hidup sehat, dan penyediaan fasilitas seperti Rumah Sakit, Rumah Bersalin, Puskesmas, Posyandu, Klinik/Balai Kesehatan, Polindes, Apotik tenaga kesehatan seperti Dokter, Perawat, Bidan.

\section{Kondisi Bidang Pertanian}

\section{Sub Sektor Tanaman Pangan}

Sub sektor tanaman pangan mencakup padi dan palawija serta hortikultura. Padi dan palawija meliputi tanaman padi (padi sawah dan padi ladang), jagung, ubi kayu, ubi jalar, kacang tanah dan kacang kedelai. Produksi padi di Kabupaten Bolaang Mongondow Selatan selama periode 2014-2015 mengalami kenaikan. Pada tahun 2014 produksi sebanyak15.352 ton naik menjadi 15.964 ton pada tahun 2015. Kanaikan ini di indikassikan karena bertambahnya luas panen yang ada.

\section{Sub Sektor Perkebunan}

Subsektor perkebunan di Kabupaten Bolaang Mongondow Selatan didominasi oleh kelapa, cengkih, kopi dan kakao. Berikut ini Tabel 6 tentang produksi tanaman perkebunan di Kabupaten Bolaang Mongondow Selatan.

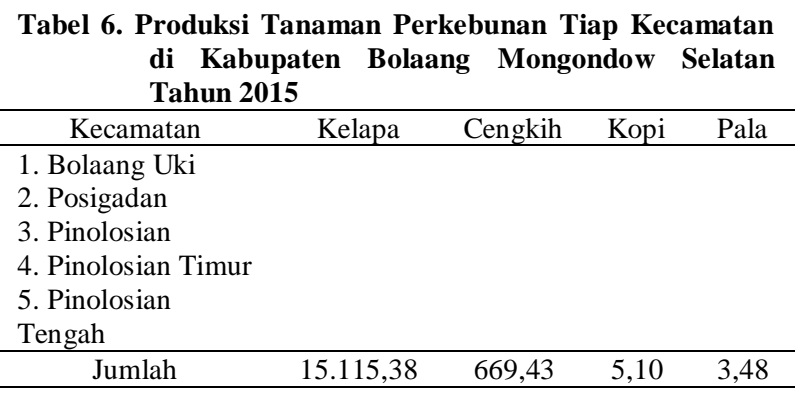

Sumber: Bolaang Mongondow Selatan dalam Angka 2016

Dari Tabel 6 kita dapat melihat bahwa kelapa merupakan komoditi perkebunan dengan hasil terbanyak dengan produksi 15.115,38 ton, produksi kelapa di dominasi oleh kecematankecamatan yang berada di pesisir. Komoditi terbanyak selanjutnya adalah cengkih, dimana produksi cengkih merata di tiap-tiap kecamatan di Kabupaten Bolaang Mongondow Selatan kecamatan dengan produksi terbanyak adalah 669,43 ton. Selanjutnya kopi dan pala dari data di Tabel 6 dapat dilihat bahwa produksi kopi di Kabupaten Bolaang Mongondow Selatan 5,10 ton, sedangkan tanaman pala dengan produksi 3,48 ton.

\section{Sub Sektor Kehutanan}

Menurut fungsinya, hutan dibagi menjadi hutan lindung, hutan produksi terbatas, hutan produksi, hutan mangrove, dan KPA. Di Kabupaten Bolaang Mongondow Selatan luas hutan adalah 135.415,71 Ha. Berikut Tabel 7 tentang luas kawasan hutan dan penggunaanya di Kabupaten Bolaang Mongondow Selatan.

Tabel 7. Luas Kawasan Hutan Dan Penggunaannya Di Kabupaten Bolaang Mongondow Selatan Tahun 2015

\begin{tabular}{|c|c|c|}
\hline Tata Guna Hutan & Luas (Ha) & Persen $(\%)$ \\
\hline 1. Hutan Lindung & $35.692,62$ & 26,36 \\
\hline 2. Hutan Produksi & & \\
\hline Terbatas & $33.150,66$ & 24,48 \\
\hline 3. Hutan Produksi & $21.353,63$ & 15,77 \\
\hline 4. Hutan Mangrove & 1000 & 0,74 \\
\hline 5. KPA & $44.218,80$ & 32,65 \\
\hline Jumlah & $135.415,80$ & 100 \\
\hline
\end{tabular}

Sub Sektor Peternakan dan Hasil-Hasilnya

Populasi ternak di Kabupaten Bolaang Mongondow Selatan terdiri dari sapi, kambing dan babi dengan produksi pada tahun 2015 berturut-turut 4148 ekor sapi, 2880 ekor kambing dan babi 578 ekor. Untuk unggas di Kabupaten Bolaang Mongondow Selatan terdapat ayam kampung 56.971, ayam petelur 1.572 , ayam pedaging 2.746 dan itik 5.848 pada tahun 2015 .

\section{Sub Sektor Perikanan}

Produksi sub sektor perikanan di Kabupaten Bolaang Mongondow Selatan pada tahun 2015 sebesar 390,94 ton, dari produksi ini didominasi oleh produksi perikanan laut sebesar 546,29 ton. 


\section{Kontribusi Sektor Pertanian Terhadap Perekonomian Kabupaten Bolaang Mongondow Selatan}

Sektor pertanian merupakan salah satu sektor penggerak perekonomian wilayah Kabupaten Bolaang Mongondow. Untuk itu, perlu dilihat seberapa besar kontribusi yang diberikan oleh sektor pertanian terhadap PDRB Kabupaten Bolaang Mongondow Selatan dalam mendorong pertumbuhan pereonomian wilayah Kabupaten Bolaang Mongondow Selatan. Persentase kontribusi sektor pertanian terhadap PDRB Kabupaten Bolaang Mongondow Selatan dari tahun 2010-2014 ditunjukkan dalam Tabel 8.

\begin{tabular}{cccc} 
Tabel 8. Kontribusi Sektor & $\begin{array}{c}\text { Pertanian Terhadap } \\
\text { Kabupaten Bolaang } \\
\text { 2010-2014 }\end{array}$ & $\begin{array}{c}\text { PDRB } \\
\text { Mongondow }\end{array}$ \\
\hline Selatan & & \\
\hline Tahun & $\begin{array}{c}\text { PDRB Sektor } \\
\text { Pertanian (juta) }\end{array}$ & $\begin{array}{c}\text { PDRB Seluruh } \\
\text { Sektor (juta) }\end{array}$ & $\begin{array}{c}\text { Kontribusi } \\
(\%)\end{array}$ \\
\hline 2010 & $330,209.8$ & $753,907.1$ & 43,79 \\
2011 & $337,751.7$ & $795,897.1$ & 42,43 \\
2012 & $355,585.2$ & $851,326.6$ & 41,76 \\
2013 & $376,281.7$ & $912,717.5$ & 41,22 \\
2014 & $390,957.2$ & $980,907.3$ & 39,85 \\
\hline Sumber: Hasil Olahan 2016 & &
\end{tabular}

Kontribusi sektor pertanian terhadap PDRB Kabupaten Bolaang Mongondow Selatan pada Tabel 8 menunjukkan bahwa pada tahun 2010 persentasenya $43,79 \%$ kemudian mengalami penurunan pada tahun 2011 dengan persentase hanya $42,43 \%$. Menurunya kontribusi sektor pertanian terhadap perekonomian Kabupaten Bolaang Mongondow Selatan terus berlanjut sampai pada tahun-tahun berikutnya dimana pada tahun 2012 kontribusinya 41,76\%, tahun 2013 $41,22 \%$ dan tahun 2014 39,85\%. Hal ini di sebabkan adanya perkembangan dari sektorsektor lainnya dalam mendukung perekonomian Kabupaten Bolaang Mongondow Selatan. Selanjutnya pada Table 9 dibahas kontribusi sektor-sektor lain dalam perekonomian Kabupaten Bolaang Mongondow Selatan selain sektor pertanian, untuk melihat perannya terhadap PDRB Kabupaten Bolaang Mongondow Selatan pada tahun 2014.
Tabel 9. Kontribusi Sektor-Sektor Perekonomian Terhadap PDRB Kabupaten Bolaang Mongondow Selatan 2014

\begin{tabular}{clc}
\hline No & \multicolumn{1}{c}{ Lapangan Usaha } & Kontribusi (\%) \\
\hline 1 & Pertanian, Kehutanan \& Perikanan & 39,85 \\
2 & Pertambangan \& Penggalian & 6,43 \\
3 & Industri Pengolahan & 0,72 \\
4 & Pengadaan Listrik, \& Gas & 0,03 \\
& Pengadaan Air, Pengelolaan & \\
5 & Sampah, Limbah \& Daur Ulang & 0,40 \\
6 & Konstruksi & 12,31 \\
& Perdagangan Besar \& Ecaran: & \\
7 & Reparasi Mobil \& Sepeda Motor & 9,12 \\
8 & Transportasi \& Pergudangan & 2,74 \\
& Penyediaan Akomodasi \& Makan & 0,40 \\
9 & Minum & 0,13 \\
10 & Informasi \& Komunikasi & 0,42 \\
11 & Jasa Keuangan \& Asuransi & 2,98 \\
12 & Real Estate & 0,01 \\
13 & Jasa Perusahaan & \\
& Administrasi Pemerintahan, & 11,81 \\
14 & Pertahanan \& Jaminan Sosial Wajib & 8,59 \\
15 & Jasa Pendidikan & 3,36 \\
16 & Jasa Kesehatan \& Kegiatan Sosial & 0,61 \\
17 & Jasa Lainnya &
\end{tabular}

Sumber: Hasil Olahan 2016

Dari Tabel 9 dapat dilihat bahwa sektor Pertanian memiliki kontributor terbesar terhadap PDRB Kabupaten Bolaang Mongondow Selatan. Hal ini mendatangkan investor sekaligus pemasukan bagi daerah.

\section{Perkembangan PDRB Sektor Pertanian Kabupaten Bolaang Mongondow Selatan Tahun 2010-2014}

Dari hasil yang disaji pada Tabel 8, terlihat bahwa kontribusi tertinggi sektor pertanian terhadap PDRB Kabupaten Bolaang Mongondow Selatan terjadi pada tahun 2010 dengan 43,79\%. Presentasenya semakin menurun dari tahun ketahun seiring berkembangnya sektor-sektor lain di Kabupaten Bolaang Mongondow Selatan. Selanjutnya perluh dilihat perkembangan nilai PDRB sektor pertanian Kabupaten Bolaang Mongondow Selatan dari tahun 2010-2014 yang disajikan dalam Tabel 10.

Tabel 10. Perkembangan Nilai PDRB Sektor Pertanian Kabupaten Bolaang Mongondow Selatan Tahun 2010-2014

\begin{tabular}{cccc}
\hline No & Tahun & PDRB Pertanian (juta) & Perkembangan (\%) \\
\hline 1 & 2010 & $330,209.8$ & \\
2 & 2011 & $337,751.7$ & 2,28 \\
3 & 2012 & $355,585.2$ & 5,28 \\
4 & 2013 & $376,281.7$ & 5,82 \\
5 & 2014 & $390,957.2$ & 3,90 \\
\hline
\end{tabular}

Sumber: Hasil Olahan 2016 
Dari Tabel 10 dapat dilihat bahwa perkembangan PDRB sektor pertanian mengalami peningkatan walaupun tidak signifikan, peningkatan signifikan PDRB sektor pertanian di Kabupaten Bolaang Mongondow Selatan terjadi pada tahun 2011 ke 2012 yaitu sebesar $5,28 \%$.

\section{Menentukan Sektor Basis Di Kabupaten Bolaang Mongondow Selatan}

Setiap daerah tentunya memiliki sektorsektor potensial yang terus menerus dikembangkan dengan berbagai upaya dari pemerintah bekerja sama dengan masyarakat. Begitu juga dengan Kabupaten Bolaang Mongondow Selatan, dimana terdapat 17 sektor salah satunya sektor pertanian. Untuk Mengetahui apakah sektor pertanian merupakan sektor basis atau sektor yang memberikan peranan paling besar terhadap perekonomian wilayah Kabupaten Bolaang Mongondow Selatan ataukah merupakan sektor non basis yaitu bukan merupakan sektor unggulan. Analisis LQ terhadap sektor-sektor di Kabupaten Bolaang Mongondow Selatan disajikan pada Tabel 11. Perhitungan LQ Kabupaten Bolaang Mongondow Selatan disajikan pada Tabel 11, sektor yang memiliki LQ > 1 merupakan sektor dan sub sektor ekonomi yang mempunyai peranan yang lebih menonjol serta memiliki keunggulan komparatif terhadap sektor dan sub sektor yang sama dalam perekonomian pada level Provinsi Sulawesi Utara. Terdapat 5 sektor di Kabupaten Bolaang Mongondow Selatan yang memiliki LQ > 1 yaitu pertanian dengan $\mathrm{LQ}=1,85$, sektor pertambangan dan penggalian dengan $\mathrm{LQ}=$ 1,32 , sektor perdangan air, pengelolaan sampah, limbah dan daur ulang dengan $\mathrm{LQ}=2,82$, sektor administrasi pemerintahan, pertahanan dan jaminan social wajib dengan $L Q=1,69$ dan yang tertinggi adalah sektor jasa pendidikan dengan $\mathrm{LQ}=3,45$. Kita dapat melihat $\mathrm{LQ}$ dari sektor pertanian tertinggal dari LQ jasa pendidikan. Tapi walaupun begitu, sektor pertanian di Kabupaten Bolaang Mongondow Selatan tetap menunjukkan perkembangan yang cukup signifikan dan juga potensi local yang dihasilkan oleh SDA di Kabupaten Bolaang Mongondow Selatan bias menjadi komoditi ekspor yang baik untuk pasar domestic maupun internasional. Sektor pertanian pun terdiri dari beberapa sub sektor yang secara langsung mendorong perekonomian wilayah yang ada di Kabupaten Bolaang Mongondow Selatan. Sub sektor yang ada ini memberikan kontribusi dan peranan yang penting guna pembangunan perekonomian wilayah. Tabel 12 akan dilihat berapa nilai LQ dari setiap sub sektor pertanian yang ada.

Tabel 11. Sektor Basis dan Non-Basis Di Kabupaten Bolaang Mongondow Selatan Tahun 2014

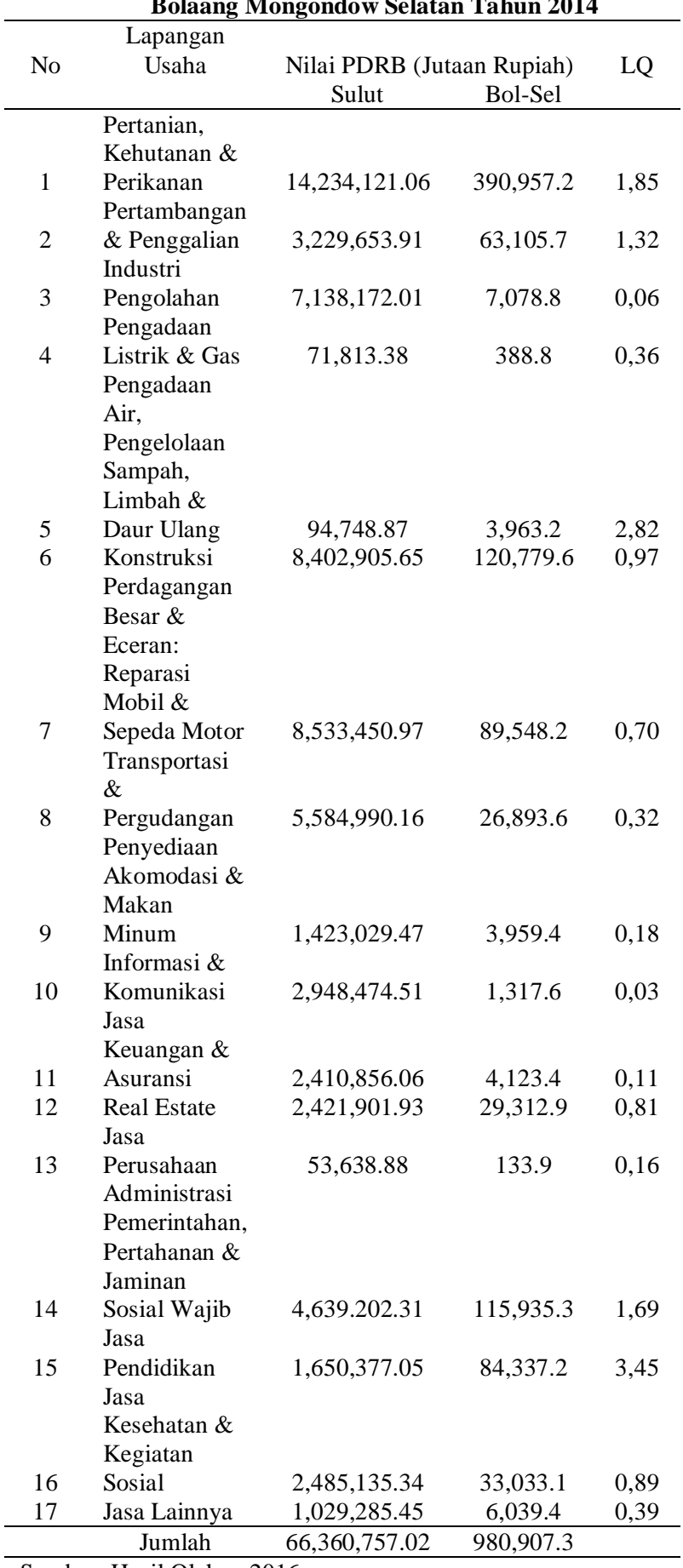

Sumber: Hasil Olahan 2016 


\section{KESIMPULAN DAN SARAN}

\section{Kesimpulan}

Dari hasil penelitian yang ada, maka diperoleh kesimpulan yaitu kontribusi sektor pertanian terhadap perekonomian Kabupaten Bolaang Mongondow Selatan dalam hal PDRB tahun 2010-2014 terus menurun, walaupun begitu sektor pertanian konsisten dan merupakan kontributor terbesar dalam memberikan kontribusi pada perekonomian Kabupaten Bolaang Mongondow Selatan dan perkembangan sektor pertanian terhadap PDRB menunjukkan peningkatan yaitu dari tahun 2010-2014 dengan peningkatan terbesar terjadi pada tahun 2013 dengan pertumbuhan mencapai $5,82 \%$, hal ini dapat di artikan bahwa produktivitas sektor pertanian di Kabupaten Bolaang Mongondow Selatan sudah baik. Dari hasil analisis menggunakan LQ, dapat diketahui bahwa sektor pertanian merupakan sektor basis di Kabupaten Bolaang Mongondow Selatan, artinya peran sektor pertanian di Kabupaten Bolaang Mongondow Selatan lebih besar.

\section{Saran}

Perlu mengoptimalkan sektor pertanian sebagai sektor basis dan di tunjang sektorsektor lainnya dan meningkatkan peran dari masing-masing sub sektor karena Kabupaten Bolaang Mongondow Selatan memiliki SDA yang baik, hanya perluh di optimalkan oleh SDM yang berkualitas.

\section{DAFTAR PUSTAKA}

Amalia. 2007. Ekonomi Pembangunan. Graha Ilmu, Yogyakarta

Arsyad. 1992. Ekonomi Pembangunan. STIE YKPN. Yogyakarta

Daniel, M. 2002. Pengantar Ekonomi Pertanian. Bumi Aksara. Jakarta

Ghalip, Rusli. 2005. Ekonomi Regional. Pustaka Ramadhan. Bandung

Irawan dan Suparmoko. 2002. Ekonomi Pembangunan. BPFF. UGM. Yogyakarta. 2002
Jhingan, M.L. 2003. Ekonomi Pembangunan Dan Perencanaan. Jakarta. PT Raja Grafindo Persada

Komalig. 2011. Peranan Sektor Pertanian Terhadap Perekonomian Kabupaten Minahasa Tenggara. Fakultas Pertanian UNSRAT. Manado. Skripsi

Kuncoro, M. 1997. Ekonomi Pembangunan. YKPN. Yogyakarta

Laoh, Esry. 2010. Buku Ajar Ekonomi Pembangunan. Jurusan Sosial Ekonomi Fakultas Pertanian. UNSRAT. Manado

Mahyudi, Ahmad. 2004. Ekonmi Pembangunan dan Analisis Data Empiris. Ghalia Indonesia. Bogor

Martono, 2000. Ekonomi Pembangunan. Universitas Sebelas Maret, Surakarta.

Riyadi dan Brathakusuma. 2005. Perencanaan Pembangunan Daerah. Gramedia Jakarta.

Soekartawi, 2003. Agribisnis, Teori dan Aplikasinya. PT Raja Grafindo. Jakarta

Soeparmoko. 2002. Perencanaan Ekonomi Wilayah. Citra Pustaka. Yogyakarta

Sukirno, S. 2006. Makro Ekonomi. Pengantar Dan Teori. Raja Grafindo Persada. Jakarta

Tarigan. 2005. Ekonomi Regional. Teori Dan Aplikasi. Bumi Aksara. Jakarta

Todaro, M dan Smith. 2004. Pembangunan Ekonomi Di Dunia Ketiga. Edisi Kedelapan Jakarta. Erlangga

Warpani, S. 2002. Analisis Kota dan Daerah. Penerbit ITB. Bandung

Widodo, 2006. Perencanaan Pembangunan: Aplikasi Komputer ( Era Otonomi Daerah). UPP STIM YKPN. Yogyakarta. 